\title{
Nonsurgical treatment of multinodular nontoxic goitre
}

Sporadic multinodular goitre is common in the UK, affecting up to $4 \%$ of the population. Spontaneous reduction in goitre size is unlikely and steady growth at about $20^{\circ}$ o per annum may be seen if untreated. Treatment is indicated for pressure symptoms on the trachea, assymmetrical increase in size suggesting underlying malignancy, a sudden increase in size due to colloid degeneration or haemorrhage, for cosmetic reasons, or to treat patient anxiety.

Traditionally, surgery has been the mainstay of treatment and has usually been a bilateral subtotal thyroid lobectomy leaving approximately $4 \mathrm{~g}$ of tissue on either side. Although the procedure rapidly relieves pressure symptoms, the goitre recurs in $10-15 \%$ of patients, the exact number depending on definition and length of follow-up but independent of whether thyroxine is given after operation. Many surgeons would employ a total lobectomy on one side and subtotal thyroidectomy on the other to make re-operative surgery safer, but the latter situation increases the possibility of complications (recurrent laryngeal palsy, hypothyroidism, and hypocalcaemia). Complications are commoner with increasing gland size, patient age and comorbidity. Additionally, some patients do not wish to undergo surgery.
Are there any reliable non-operative approaches? Thyroid suppression with either thyroxine or triiodothyronine, although effective transiently in diffuse nontoxic goitre, is probably without benefit in multinodular goitre. ${ }^{1-3}$ This is because it is largely normal thyroid tissue that is suppressed leaving the colloid nodules to expand and calcify. In iodine-deficient goitre, dietary supplementation alone may be appropriate. Recently, Nygard and others reported the use of ${ }^{131} I$ in the successful treatment of 69 patients with growing multinodular nontoxic goitre causing local compression symptoms or cosmetic problems. ${ }^{4} \mathrm{~A}$ single intravenous dose of $3.7 \mathrm{MBq}{ }^{131} \mathrm{I} / \mathrm{g}$ thyroid tissue was used ( $30 \mathrm{mCi}$ maximum) and the patients were followed for a median of 48 months. A few patients needed repeat treatment. The overall decrease of ultrasonically determined thyroid volume was $34 \%$ after 12 months and $55 \%$ after 24 months. There were no cases of exacerbation of obstructive symptoms: the 5-year risk of hypothyroidism was $22 \%$. Symptom relief was in general good.

In conclusion, the majority of patients with sporadic nontoxic multinodular goitre should be treated by unilateral total thyroid lobectomy and contralateral subtotal lobectomy. In some unfit patients or those with recurrent problems radioiodine deserves further investigation as antion, perhaps initially in a controlled clinical trial setting.

ANJAN BANERJEE JUHN COOPER Department of Surgery, Rotherham District General Hospital, Moorgate Road, Rotherham S60 2UH, UK

- sporadic multinodular goitre is common in the UK

- the majority can be managed conservatively

- surgery remains the mainstay of treatment

- in selected patients, radioiodine may be an option

1 Berghout A, Wiersinga WM, Drexhage HA, Smits NJ, Touber JL. Comparison of placebo with $\mathrm{L}$-thyroxine alone or with carbimazole for treatment of sporadic non-toxic goitre. Lancet 1990; 336: 193-7.

2 Gharib H, James EM, Charboneau JW, Naessens JM, Offord KP, Gorman CA. Suppressive therapy with levothyroxine for solitary thyroid nodules. A CA. Suppressive therapy with levothyroxine for solitary thyroid nodules.
double-blind controlled clinical study. $N$ Engl f Med 1987; 317: 70-5.
The release of the film The Madness of King George has brought the disease of porphyria full in the public domain. From the first signs of the King's illness, his gastrointestinal distress, his blue-tinged urine, to his complete mental collapse and subsequent, almost miraculous, recovery, the film paints a classic portrait of porphyria. However, the use of this rare disease to explain one of history's great abberations has also been extrapolated by the media, and erroneously so, to the realm of the vampire.

Although a fascinating concept, for most of us today, the vampire is a myth, easily dismissed as mere fiction to be enjoyed at the cinema or on the printed page. However, during the 18th century, the age of the folkloric or mythic vampire, Eastern Europe in particular, was rife with reports of vampire citings. So prevalent was the belief in the existence of a literal vampire, that the Austrians, occupying Serbia during the 1730 s, dispatched a team of medical officers to a Serbian town to investigate the weekly exhumations and 'killing' of the dead.'

One modern but now prevalent explanation of the myth can be summed up in one word, porphyria. The genesis of this theory might have begun in an article in the New York Times in May 1985. In a speech to the American Association for the Advancement of Science, Dr David H Dolphin announced that 'werewolves and vampires those dreaded beasts of folklore and superstition, may have been nothing 
more than people suffering from a rare class of genetic disease'. ${ }^{2} \mathrm{He}$ went on to say that signs and symptoms commonly associated with vampirism, ie, protruding teeth, avoidance of sunlight, drinking blood, and (sometimes) disfigurement, could have been exhibited by sufferers of porphyria.

Classed by their exhibition of symptoms in two ways, neurological and photosensitive (dermatological), the porphyrias, a group of rare genetic and acquired diseases of the blood, result when the production and synthesis of haemoglobin go awry. ${ }^{3,4}$ The rarest and most horrific form of the porphyrias, which is not only considered a viable explanation for vampires but also doubles quite nicely for werewolves, is congenital erythropoietic porphyria. Not more than 200 cases have so far been diagnosed. ${ }^{5}$ Beginning in early childhood, congenital erythropoietic porphyria manifests itself in extreme sensitivity to light (sun). On exposure to light the skin blisters, and with infection can become so severely scarred as to leave the individual quite disfigured. Treatment for sufferers could involve blood transfusions, but the only effective treatment is bone marrow transplantation. ${ }^{6,7}$

On the surface, the vampiristic aspects of congenital erythropoietic porphyria are quite evident. Avoidance of sunlight and the need to ingest blood, as Dr Dolphin suggests, may have driven its victims to 'suck the blood of their brothers and sisters'. However, the folkloric vampire was a very different creature to the one we are generally familiar with in the 20th century. An important difference was the belief that it was not uncommon for the vampire to be active out-of-doors while the sun shone. In 18th and 19 th century Europe there were accounts of vampire citings occurring in daylight hours. ${ }^{8}$ Even Stoker's Dracula was observed taking an afternoon stroll through London's crowded streets.

As it was believed that the folkloric vampire could move about freely in daylight hours, as opposed to the 20th century variant, congenital erythropoietic porphyria cannot readily explain the folkloric vampire but may be an explanation of the vampire as we know it in the 20th century. In addition, the folkloric vampire, when unearthed, was always described as looking quite healthy ('as they were in life'), while due to the disfiguring aspects of the disease, sufferers would not have passed the exhumation test. Individuals with congenital erythropoietic porphyria

1 Barber P. The real vampire: forensic pathology and the lore of the undead Nat Hist 1990; (October) 74-83.

2 Boffey PM. Rare disease proposed as cause for 'vampire'. New York Times 31 May, 1985; A15.

3 Meola T, Lim HW. The porphyrias. Dermatol Clin 1993; 11: 583-96.

4 Moore MR. Biochemistry of porphyria. Int $\mathcal{f}$ Biochem 1993; 25: 1353-68

5 Kushner JP. Laboratory diagnosis of the porphyrias. N Engl $\mathcal{F}$ Med 1991 324: $1432-4$.

\section{Congenital erythropoietic porphyria: key} characteristics

- the disease is so rare that only about 200 cases have been diagnosed to date

- patients are extremely sensitive to light (sun), ie, cannot tolerate it

- when exposed to light, patients are prone to severe scarring and disfigurement

- sufferers do not crave blood

\section{The folkloric vampire: key characteristics}

- belief in their existence was rampant in Eastern Europe in the 18 th and 19 th centuries; in some villages, they were unearthed weekly

- they are believed to have been able to tolerate sunlight surprisingly well

- in appearance, they were often described as quite healthy looking

- they are believed to have had unquenchable craving for blood

do not crave blood. The enzyme (haematin) necessary to alleviate the symptoms is not absorbed intact on oral ingestion, and drinking blood would have no beneficial effect for the sufferer. ${ }^{9}$ Finally, and most important, the fact that vampire reports were literally rampant in the 18th century, and that congenital erythropoietic porphyria is an extremely rare manifestation of a rare disease, makes it an unlikely explanation of the folkloric vampire.

However, all this notwithstanding, as late as this winter, the US television channel, The Learning Channel (one could turn many phrases here), broadcast a documentary on vampires in which the chief medical expert, one $\mathrm{Dr}$ Dolphin, steadfastly continued the promotion of the vampire-porphyria association.

ANN M COX

McGill University, Montreal, Quebec H3A 1 Y1 Canada

Correspondence to AM Cox, 721 Canning St, Montreal, Quebec H3J 2A3, Canada

6 Hoffman R, ed. Hematology: basic principles and practice. New York: Churchill Livingstone, 1991; p 357.

7 Kauppinen R, Timomen K, Mustajoki P. Treatment of the porphyrias. Ann Med 1994; 26: $31-8$

8 Copper B. The vampire in legend, fact and art. Secaucus, NJ: The Citadel Press, 1974; pp 154-6.

9 Winkler G, Anderson KE. Vampires, porphyria, and the media: medicalization of a myth. Perspect Biol Med 1990; 33: 598-611. 